As-Syifaa Jurnal Farmasi Desember 2020;12(2):131-135.

ISSN : 2502-9444 (electronic); 2085-4714 (printed)

Journal Homepage : http://jurnal.farmasi.umi.ac.id/index.php/as-syifaa

\title{
UJI EFEKTIVITAS EKSTRAK ETANOL KULIT PISANG MAS (Musa Acuminata Colla) TERHADAP PENURUNAN KADAR KOLESTEROL TIKUS (Rattus norvegicus) HIPERLIPIDEMIA
}

\author{
Sukmawati, Aulia Wati, Mega Meilinda \\ Fakultas Farmasi, Universitas Muslim Indonesia, Makasssar \\ Email : megamlinda144@gmail.com
}

\begin{abstract}
Hyperlipidemia is the escalation level of cholesterol and triglyceride in blood. Lady finger banana peel had chemical flavonoid, tanin, and saponin contents having the activity to reduce cholesterol level. The research aimed to determine the effect of cholesterol level reduction of ethanol exctract of lady finger peel on hyperlipidemia rat. The research used twenty rats divided into five groups. Group I (negative control) was given Na. CMC of $1 \% \mathrm{~b} / \mathrm{v}$, group II (positive control) was given simvastatin of $1,023 \mathrm{mg} / \mathrm{kgBW}$, group III, IV, V groups were given the extract of $500 \mathrm{mg} / \mathrm{kgBW} 1000$ $\mathrm{mg} / \mathrm{kgBW}$, and $1500 \mathrm{mg} / \mathrm{kgBW}$. The rats were fed a high dietary fat during treatment and induces with pristine cholesterol for twenty one days. The measurement of rat cholesterol level was conducted on day 0, 22 and 36. The result were statistically processed using One Way Anova proceeded to Post Hoc Bonferroni. The result of the research showed that the positive control group had no different tangible effect to ethanol extract of lady finger banana groups $(p>0,5)$. In conclusion, the ethanol extract of lady finger banana had the activity in reducing cholesterol level with effective doses of $500 \mathrm{mg} / \mathrm{kgBW}, 1000$ $\mathrm{mg} / \mathrm{kgBW}$, and $1500 \mathrm{mg} / \mathrm{kgBW}$.
\end{abstract}

Key words : Lady Finger Banana Peel (Musa acuminata Colla), Cholesterol, Hyperlipidemia.

\section{PENDAHULUAN}

Hiperlipidemia merupakan keadaan dimana terjadi peningkatan kadar lemak darah meliputi peningkatan kadar kolesterol total, kolesterol LDL (Low Density Lipoprotein) dan trigliserida. Kolesterol merupakan salah satu parameter hiperlipidemia. Kadar kolesterol yang tinggi merupakan salah satu faktor terjadinya aterosklerosis. ${ }^{1,2}$ Aterosklerosis merupakan kondisi terjadinya penimbunan plak yang mengandung kolesterol dan kolesterol ester pada lapisan dinding pembuluh darah, ditandai dengan penebalan dan hilangnya elastisitas dinding pembuluh darah arteri. Pembentukan plak ini akan memperlambat bahkan meng-hentikan aliran darah menuju jaringan target, akibatnya jaringan tersebut akan kekurangan oksigen dan nutrisi. Aterosklerosis menyebabkan terjadinya penyakit jantung koroner, stroke dan penyakit



Riset Kesehatan Dasar bidang biomedis tahun 2013 melaporkan bahwa prevalensi hiperlipidemia di Indonesia atas dasar konsentrasi kolesterol total di atas nilai normal adalah $35,9 \%$. Kadar kolesterol diatas normal pada perempuan lebih tinggi dibandingkan pada laki-laki dengan persentase $39,6 \%$ dan $30 \%$, dan di daerah perkotaan lebih tinggi dibandingkan di daerah perdesaan dengan persentase $39,5 \%$ dan $32,1 \% .{ }^{4}$

Pisang merupakan salah satu buah yang paling banyak dikonsumsi secara langsung atau diolah menjadi produk 
Uji Efektivitas Ekstrak Etanol Kulit Pisang Mas (Musa acuminata Colla) Terhadap Penurunan Kadar Kolesterol Tikus (Rattus norvegicus) Hiperlipidemia

konsumsi. Namun, hal ini tidak diimbangi dengan pengolahan limbah kulit pisang yang dihasilkan. Kulit pisang merupakan sumber potensial senyawa flavonoid dan fenolik. ${ }^{5,6}$ Kulit pisang mas (Musa acuminata Colla) mengandung flavonoid, tanin, dan saponin yang memiliki aktivitas dalam menurunkan kadar kolesterol. ${ }^{7}$ Ekstrak etanol kulit pisang mas memiliki aktivitas antioksidan kuat dengan nilai $\mathrm{IC}_{50}$ terhadap DPPH sebesar 70,41 mg/L. ${ }^{5}$ Penelitian Rosida (2018) mengenai aktivitas ekstrak kulit pisang (Musa acuminata) menunjukkan bahwa ekstrak etanol kulit pisang mas dapat menurunkan kadar kolesterol total pada mencit hiperkolesterolemia.

Berdasarkan uraian diatas maka dilakukan uji efektivitas ekstrak etanol kulit pisang mas (Musa acuminata Colla) terhadap penurunan kadar kolesterol tikus hiperlipidemia.

\section{METODE PENELITIAN}

\section{Alat dan bahan}

Alat-alat yang digunakan yaitu seperangkat alat kaca, batang pengaduk, gelas arloji, gelas kimia, gunting, human analyzer (Microlab 300), kandang tikus, kanula, kertas saring, lap kasar, lap halus, mikropipet, oven, pinset, restrainer tikus, sendok tanduk, sentrifuge, spoit, tabung Eppendorf, toples, timbangan analitik (OHaus), timbangan hewan, rotavapor, tip mikropipet, vial, dan vortex (Mixer). Bahan-bahan yang di-gunakan yaitu alumunium foil, aquadest, betadin, etanol $96 \%$, kulit pisang mas (Musa acuminata Colla), kapas, kertas saring, $\mathrm{Na}$. CMC 1\%, pakan diet tinggi lemak (DTL), reagen pengujian kolesterol total, dan simvastatin ${ }^{\circledR}$.

\section{Prosedur kerja}

Pembuatan suspensi simvastatin 1,023 $\mathrm{mg} / \mathrm{kgBB}$
Tablet simvastatin $^{\circledR}$ ditimbang sebanyak 10 tablet dan dihitung berat rataratanya. Setelah itu, tablet digerus di dalam lumpang kemudian ditimbang sebanyak 24,112 mg serbuk simvastatin, lalu disuspensikan dengan $10 \mathrm{~mL} \mathrm{Na-CMC} \mathrm{1 \%} \mathrm{b/v.}$

\section{Pembuatan pakan diet tinggi lemak (DTL)}

Pakan diet tinggi lemak, tiap $1 \mathrm{~kg}$ dibuat dengan cara mencampur tepung gandum 150 $\mathrm{g} / \mathrm{kg}$, tepung jagung $540 \mathrm{~g} / \mathrm{kg}$, tepung kacang hijau $100 \mathrm{~g} / \mathrm{kg}$, kuning telur bebek $10 \mathrm{~g} / \mathrm{kg}$, dan lemak sapi $200 \mathrm{~g} / \mathrm{kg}$. Setelah semua bahan tercampur rata, adonan dibuat dalam bagianbagian kecil lalu dikeringkan menggunakan oven.

Pembuatan kolesterol murni dosis 200 $\mathrm{mg} / \mathrm{kgBB}$

Kolesterol murni ditimbang sebanyak $1000 \mathrm{mg}$ lalu dilarutkan dalam $50 \mathrm{~mL}$ minyak kelapa.

Pembuatan suspensi ekstrak etanol kulit pisang mas (Musa acuminata Colla)

Suspensi ekstrak etanol kulit pisang mas (Musa acuminata Colla) dosis 500 $\mathrm{mg} / \mathrm{kgBB}, 1000 \mathrm{mg} / \mathrm{kgBB}$, dan $1500 \mathrm{mg} / \mathrm{kgBB}$ dibuat dengan cara menimbang masingmasing ekstrak sebanyak $500 \mathrm{mg}, 1000 \mathrm{mg}$, dan $1500 \mathrm{mg}$, kemudian disuspensikan dengan $10 \mathrm{~mL} \mathrm{Na-CMC} \mathrm{1 \%} \mathrm{b/v.}$

\section{Perlakuan hewan uji}

Dilakukan pengukuran kadar kolesterol awal sebelum induksi pada hari ke- 0 . Kemudian, tikus tersebut dikelompokkan menjadi 5 kelompok dengan jumlah 4 ekor tikus tiap kelompok. Tikus diinduksi kolesterol murni secara oral dan diberikan pakan diet tinggi lemak (DTL) secara ad libitum selama 21 hari. Pada hari ke-22 dilakukan pengukuran kadar kolesterol tikus setelah diinduksi. Kemudian, tikus diberi perlakuan sediaan uji secara oral 
Uji Efektivitas Ekstrak Etanol Kulit Pisang Mas (Musa acuminata Colla) Terhadap Penurunan Kadar Kolesterol Tikus (Rattus norvegicus) Hiperlipidemia

dan pakan DTL secara ad libitum sebanyak satu kali sehari hingga hari ke-35. Sediaan uji yang diberikan adalah sebagai berikut :

a. Kelompok I (kontrol negatif), diberikan NaCMC $1 \%$.

b. Kelompok II (kontrol positif), diberikan simvastatin dosis $1,023 \mathrm{mg} / \mathrm{kgBB}$.

c. Kelompok III, diberikan ekstrak etanol kulit pisang mas (Musa acuminata Colla) dosis $500 \mathrm{mg} / \mathrm{kgBB}$.

d. Kelompok IV, diberikan ekstrak etanol kulit pisang mas (Musa acuminata Colla) dosis $1000 \mathrm{mg} / \mathrm{kgBB}$.

e. Kelompok V, diberikan ekstrak etanol kulit pisang mas (Musa acuminata Colla) dosis $1500 \mathrm{mg} / \mathrm{kgBB}$.

Pada hari ke-36 dilakukan pengukuran kadar kolesterol tikus setelah diberi sediaan uji (akhir). Tikus dipuasakan terlebih dahulu selama 14-18 jam setiap sebelum pengambilan darah.

\section{Proses pengambilan sampel darah}

Darah diambil melalui vena lateralis pada bagian ekor tikus. Ekor tikus dijulurkan, kemudian vena lateralis pada ekor tikus dipotong $0,2 \mathrm{~cm}$ dari ujung ekor Darah ditampung pada tabung Eppendorf sebanyak $0,5 \mathrm{~mL}$, kemudian disentrifug selama 10 menit dengan kecepatan $3000 \mathrm{rpm}$, lalu diambil serumnya (lapisan bening).

\section{Pengukuran kadar kolesterol darah tikus}

Serum darah tikus diambil sebanyak 3 $\mu \mathrm{L}$, lalu ditambahkan dengan $300 \mu \mathrm{L}$ reagen kolesterol, divortex dan diinkubasi selama 5 menit 25 detik. Kadar kolesterol diiukur menggunakan alat Human Analyzer (Microlab 300) pada panjang gelombang $500 \mathrm{~nm}$.

\section{HASIL DAN PEMBAHASAN}

Tabel 1. Hasil pengukuran rata-rata kadar kolesterol hewan uji antar kelompok perlakuan.

\begin{tabular}{lccc}
\hline \multirow{2}{*}{$\begin{array}{c}\text { Kelompok } \\
\text { Perlakuan }\end{array}$} & \multicolumn{3}{c}{ Rata-Rata Kadar Kolesterol (mg/dl) \pm SD Hari Ke- } \\
\cline { 2 - 4 } & $\mathbf{0}$ & $\mathbf{2 2}$ & $\mathbf{3 6}$ \\
\hline I (Kontrol negatif) & $41,00 \pm 11,05$ & $85,50 \pm 17,69$ & $82,75 \pm 8,88$ \\
II (Kontrol positif) & $42,50 \pm 9,95$ & $85,25 \pm 6,85$ & $22,75 \pm 7,97$ \\
III (EEKPM 500 mg/kgBB) & $42,00 \pm 8,12$ & $86,50 \pm 4,20$ & $27,00 \pm 10,49$ \\
IV (EEKPM 1000 mg/kgBB) & $40,25 \pm 6,08$ & $85,75 \pm 4,35$ & $35,25 \pm 12,82$ \\
V (EEKPM 1500 mg/kgBB) & $39,50 \pm 7,42$ & $85,75 \pm 5,62$ & $34,25 \pm 18,01$ \\
\hline Ket : EEKPM : Ekstrak Etanol Kulit Pisang Mas (Musa acuminata Colla) & &
\end{tabular}

Kolesterol merupakan salah satu jenis lipid dalam darah yang diproduksi oleh oleh tubuh manusia terutama di hati. Kolesterol berfungsi sebagai molekul prekursor yang penting dalam sintesis vitamin $\mathrm{D}$ dan hormon steroid, termasuk kelenjar hormon adrenal kortisol, aldosteron, hormon seks progesteron, estrogen dan testosteron serta turunannya. Sampel yang digunakan adalah ekstrak etanol kulit pisang mas (Musa acuminata Colla) (EEKPM). EEKPM diperoleh melalui proses ekstraksi kulit pisang mas sebanyak 500 mg menggunakan metode maserasi. Metode maserasi digunakan karena merupakan metode yang sederhana, sesuai untuk sampel yang bertekstur lunak, dan dapat digunakan untuk senyawa yang tahan terhadap pemanasan maupun yang tidak tahan terhadap pemanasan. ${ }^{8}$ Ektrak kental yang diperoleh dari ekstraksi adalah 47,57 gram dengan persen rendemen $9,514 \%$. Pemilihan variasi dosis yang digunakan berdasarkan pada penelitian 
Uji Efektivitas Ekstrak Etanol Kulit Pisang Mas (Musa acuminata Colla) Terhadap Penurunan Kadar Kolesterol Tikus (Rattus norvegicus) Hiperlipidemia

sebelumnya yang dilakukan oleh Rosida (2018) menunjukkan bahwa ekstrak etanol kulit pisang mas dosis $40 \mathrm{mg} / 20 \mathrm{gBB}$ dapat menurunkan kadar kolesterol total pada mencit hiperkolesterolemia.

Hewan uji yang digunakan adalah tikus jantan (Rattus norvegicus) galur wistar yang merupakan galur paling umum yang digunakan dalam penelitian dan mudah diperoleh. Tikus jantan memiliki sistem hormonal yang lebih stabil dibandingkan tikus betina. ${ }^{9,10}$ Tabel 1 menunjukkan bahwa semua kelompok perlakuan memiliki kadar kolesterol awal yang normal, yaitu berkisar antara 39,5-42,5 mg/dL. Nilai ini sesuai dengan kadar kolesterol normal tikus yaitu $10-54 \mathrm{mg} / \mathrm{dL} .{ }^{11}$

Setelah dilakukan induksi selama 21 hari dengan pemberian kolesterol murni 200 $\mathrm{mg} / \mathrm{kgBB}$ dan pakan DTL, terjadi peningkatan kadar kolesterol melebihi kadar normal pada semua kelompok Hal ini menunjukkan bahwa kondisi hiperkolesterolemia pada tikus hiperlipidemia tercapai.

Tabel 2. Rata-rata persentase penurunan kadar kolesterol antar kelompok perlakuan

\begin{tabular}{cc}
\hline Kelompok Perlakuan & Rata-rata penurunan kadar kolesterol (\%) \\
\hline I (Kontrol negatif) & $0,95 \%^{\mathrm{a}}$ \\
II (Kontrol positif) & $73,56 \% \%^{\mathrm{b}}$ \\
III (EEKPM $500 \mathrm{mg} / \mathrm{kgBB})$ & $68,68 \%$ \\
IV (EEKPM $1000 \mathrm{mg} / \mathrm{kgBB})$ & $59,03 \%$ \\
V (EEKPM $1500 \mathrm{mg} / \mathrm{kgBB})$ & $59,27 \%$
\end{tabular}

Ket : EEKPM : Ekstrak Etanol Kulit Pisang Mas (Musa acuminata Colla); ${ }^{a} \mathrm{P}<0.05$ dengan semua kelompok perlakuan (Bonferroni test); ${ }^{\mathrm{b}} \mathrm{P}>0.05$ dengan ketiga kelompok dosis kombinasi (Bonferroni test)

Pakan diet tinggi lemak yang dikonsumsi akan menyebabkan peningkatan jumlah lemak dalam bentuk trigliserida. Lemak tersebut akan terdeposit pada jaringan adiposa terutama yang berada dibawah kulit dan di rongga perut, dan jika jumlahnya berlebih maka sewaktu-waktu akan digunakan sebagai bahan pembentukan VLDL dan LDL di hati, sehingga dapat mempengaruhi kadar kolesterol total. ${ }^{12}$ Kadar kolesterol tikus menjadi normal kembali pada tiap kelompok perlakuan setelah diberikan sediaan uji selama 14 hari, kecuali pada kontrol negatif yang diberikan $\mathrm{Na}$. CMC $1 \%$ yang merupakan kontrol negatif. Simvastatin $^{\circledR}$ merupakan obat terapi farmakologi yang digunakan untuk menurunkan kadar kolesterol yang tinggi, dengan mekanisme kerja menghambat enzim 3-hydroxy-3-methyl-glutaryl-coenzim reductase (HMG-CoA reduktase) pada proses sintesis kolesterol di hati. $^{13}$ Tabel 2 menunjukkan persentase penurunan kolesterol setelah terapi selama 14 hari. Kelompok perlakuan yang mengalami penurunan paling tinggi adalah pada kelompok kontrol positif (simvastatin ${ }^{\circledR}$ ) yaitu sebesar $73,56 \%$, kemudian diikuti dengan kelompok EEKPM $500 \mathrm{mg} / \mathrm{kgBB}$ (68,68\%), EEKPM 1500 mg/kgBB (59,27\%) dan $1000 \mathrm{mg} / \mathrm{kgBB}$ (59,03\%). Nilai rata-rata persen penurunan tersebut menunjukkan bahwa EEKPM memiliki efek dalam menurunkan kadar kolesterol tikus hiperlipidemia.

Flavonoid menurunkan kadar kolesterol dalam darah dengan cara menghambat aktivitas dari enzim 3-hydroxy-3methyl-glutaryl-coenzim A reductase (HMGCoA reductase) sehingga sintesis kolesterol terhambat. Flavonoid juga bekerja dengan cara menghambat aktivitas enzim acyl-CoA 
Uji Efektivitas Ekstrak Etanol Kulit Pisang Mas (Musa acuminata Colla) Terhadap Penurunan Kadar Kolesterol Tikus (Rattus norvegicus) Hiperlipidemia

cholesterol acyl transferase (ACAT) sehingga

terjadi penurunan esterifikasi kolesterol pada usus dan hati. ${ }^{14}$ Saponin berikatan dengan asam empedu dan kolesterol membentuk misel sehingga dapat menurunkan reabsorpsi kolesterol. Sedangkan tanin di dalam tubuh akan berikatan dengan protein tubuh dan melapisi dinding usus, sehingga penyerapan lemak terhambat. Hal ini menyebabkan pembentukan dan penyerapan kolesterol di usus terhambat. ${ }^{15}$

\section{KESIMPULAN}

Ekstrak etanol kulit pisang mas (Musa acuminata Colla) memiliki efek terhadap penurunan kadar kolesterol tikus hiperlipidemia. Ekstrak etanol kulit pisang mas (Musa acuminata Colla) yang efektif menurunkan kadar kolesterol tikus hiperlipidemia adalah dosis $500 \mathrm{mg} / \mathrm{kgBB}$, $1000 \mathrm{mg} / \mathrm{kgBB}$, dan $1500 \mathrm{mg} / \mathrm{kgBB}$.

\section{DAFTAR PUSTAKA}

1. Khomsan A. Rahasia Sehat dengan Makanan Berkhasiat. Kompas. Jakarta, 2009:203.

2. Dalimarta S and Dalimarta FA. Tumbuhan Sakti Atasi Kolesterol. Jakarta. Penebar Swadaya, 2012:8-11.

3. Wihastuti TA, Andarini S, and Heriansyah T. Patofisiologi Dasar Keperawatan Penyakit Jantung Koroner : Inflamasi Koroner. Malang. UB Press, 2016:5-6.

4. Kemenkes RI. Riset Kesehatan Dasar. Jakarta. Departemen Kementerian Kesehatan Republik Indonesia, 2013:259.

5. Rosida and Diyan RAA. Penentuan Aktivitas Antioksidan dan Kadar Fenol Total pada Ekstrak Kulit Buah Pisang (Musa acuminata Colla). Seminar Nasional Farmasi Jember, Jember, 2015:26.

6. Singhal $M$ AND Ratra $P$. Antioxidant Activity, Total Flavonoid and Total Phenolic Content of Musa acuminate Peel Extract. Global Journal Pharmacology.2013;7:118-122.
7. Rosida, Rosetyowati DA and Inawati Y. Aktivitas Ekstrak Kulit Pisang (Musa acuminata) terhadap Penurunan Kadar Kolesterol Total Darah Mencit Hiperkolesterolemia. Seminar Nasional Biologi dan Pendidikan Biologi, Salatiga, Jawa Tengah, 2018:142.

8. Unon MA. Buku Ajar Ekstraksi dan Real Kromatografi. Yogyakarta. Deepublish, 2017:3.

9. Warsono IU, Fattah MW and Parakkasi A. Pengaruh Tepung Cangkang Rajungan (Portunus pelagicus) dalam Ransum terhadap Kadar Kolesterol Serum dan Pertambahan Bobot Badan Tikus Putih (Rattus norvegicus). Media Peternakan. 2004:56.

10. Fitria L, Mulyati, Tiraya MC and Budi A. Profil Reproduksi Jalan Tikus (Rattus norvegicus) Galur Wistar Stadia Muda, Pradewasa, dan Dewasa. Jurnal Biologi Papua. 2015:29-30.

11. Mitruka BM and Rawnsley HM. Clinical Biochemical and Hematological Reference Value in Normal Experimental Animals. USA. Masson Publishing, 1997:3-6 \& 123.

12. Tsalissavrina I, Wahono $D$, and Handayani D. Pengaruh Pemberian Diet Tinggi Karbohidrat dibandingkan Diet Tinggi Lemak terhadap Kadar Trigliserida dan HDL Darah. Jurnal Kedokteran Brawijaya. 2006;12(2).

13. Katzung BG, Masters SB, Trevor, AJ. Farmakologi Dasar Dan Klinik, Vol. 2, edk 12. Jakarta. EGC, 2013:704-710.

14. Pradana DA, Rahmah FS, and Setyaningrum TR. Potensi Antihiperlipidemia Ekstrak Etanol Daun Bayam Merah (Amaranthus tricolor L.) Terstandar secara In Vivo Berdasarkan Parameter LDL (Low Density Lipoprotein). Jurnal Sains Farmasi \& Klinis. 2016;2:23127.

15. Arief MI, Novriansyah $R$, Budianto IT, Harmaji MB. Potensi Bunga Karamunting (Melastoma malabathricum L.) terhadap Kadar Kolesterol Total dan Trigliserida pada Tikus Putih Jantan Hiperlipidemia yang Diinduksi Propiltiourasil. Prestasi. 2012;1(2):124. 